\title{
PERANAN DAN TANGGUNGJAWAB PEMERINTAH DALAM PELAYANAN KESEHATAN PASCA BERLAKUNYA UU CIPTA KERJA
}

\author{
Weppy Susetiyo, Anik Iftitah; Fakultas Hukum Universitas Islam Balitar; E-mail: \\ anikiftitahblitar@gmail.com
}

\begin{abstract}
Abstrak
Ada lima undang-undang bidang kesehatan yang diubah pasca pemberlakuan UU Cipta Kerja. Mengingat dampak pemberlakuan UU Cipta Kerja yang luar biasa mengubah peraturan perundang-undangan di sektor kesehatan, menjadi sangat penting untuk menganalisis peranan dan tanggungjawab pemerintah dalam pelayanan kesehatan pasca berlakunya UU Cipta Kerja sebagai bagian pemberlakuan Omnibus Law di Indonesia. Melalui penelitian yuridis normatif, dihasilkan penelitian bahwa pemerintah sebagai penanggungjawab terhadap perencanaan, pengaturan, penyelenggaraan, pembinaan, dan pengawasan penyelenggaraan upaya kesehatan yang merata dan terjangkau oleh masyarakat, melalui UU Ciptaker mengubah aturan di bidang kesehatan seperti penyederhanaan pasal-pasal dalam UU Kesehatan dan UU Rumah Sakit, jasa pelayanan kesehatan medis tidak dikenakan PPN, pemberian jasa pelayanan kesehatan medis tidak hanya pada tenaga kesehatan dan asisten tenaga kesehatan, dan mengharuskan rumah sakit melakukan akreditasi setiap tiga tahun sekali. Terkait hal tersebut, pemerintah berperan mengatur praktik pelayanan kesehatan di rumah sakit berupa pembinaan dan pengawasan terhadap rumah sakit, meminimalisir pembuatan kebijakan yang merugikan kepentingan tenaga kesehatan yang bekerja di rumah sakit, dan memastikan masyarakat mendapatkan pelayanan kesehatan sesuai ketentuan pelayanan publik, kompetensi, dan standar operasional prosedur.
\end{abstract}

Kata Kunci: Pelayanan Kesehatan, UU Cipta Kerja, Tanggung Jawab Pemerintah, Peranan Pemerintah

\section{Abstract}

Five health laws were amended after the creation of the Job Creation Law. Given the extraordinary impact of the enactment of the Job Creation Law in changing the laws and regulations in the health sector, it is very important to analyze the role and responsibility of the government in health services after the enactment of the Job Creation Law as part of the implementation of the Omnibus Law in Indonesia. Through normative juridical research, research is produced that the government as the person in charge of planning, regulating, implementing, fostering, and supervising the implementation of health efforts that is equitable and affordable by the community, through the Ciptaker Law changes the rules in the health sector such as simplifying the articles in the Health Law and the Law on Health. Hospitals, medical health services are not subject to VAT, the provision of medical health services is not only for health workers and assistant health workers, and requires hospitals to carry out accreditation every three years. Related to this, the government plays a role in regulating the practice of health services in hospitals in the form of fostering and supervising hospitals, minimizing policymaking that harms the interests of health workers working in hospitals, and ensuring that the community gets health services by the provisions of public services, competencies, and standards. operational procedures.

Keywords: Health Services, Job Creation Law, Government Responsibilities, Government Role

\section{PENDAHULUAN}

\section{Latar Belakang}

Indonesia sebagai negara yang menganut konsep welfare state dengan konsekuensi bertanggung jawab dan memainkan peran kunci terhadap kesejahteraan warganya ${ }^{1}$ sebagaimana yang termaktub dalam Pembukaan Konstitusi Indonesia (Undang-Undang

\footnotetext{
${ }^{1}$ Alfitri, (2012). Ideologi Welfare State dalam Dasar Negara Indonesia: Analisis Putusan Mahkamah Konstitusi Terkait Sistem Jaminan Sosial Nasional. Jurnal Konstitusi, Volume 9, Nomor 3, September 2012, h. 454.
} 
Dasar Negara Republik Indonesia Tahun 1945) Alinea ke-IV ${ }^{2}$ dan pasal 28H ayat 1 Undang-Undang Dasar Negara Republik Indonesia Tahun 1945 (UUD NRI 1945) bahwa, "Setiap orang berhak hidup sejahtera lahir dan batin, bertempat tinggal, dan mendapatkan lingkungan hidup yang baik dan sehat serta berhak memperoleh pelayanan kesehatan." Dalam hal pelayanan kesehatan, peraturan perundang-undangan tersebut secara eksplisit memberikan kepastian hukum bahwa pemerintah Indonesia memiliki kewajiban untuk menghormati, melindungi, menegakkan, dan memenuhi pelayanan kesehatan warga Negara Indonesia. Dan dalam memenuhi kewajiban tersebut pemerintah memiliki wewenang untuk melakukan pengaturan dan pengurusan dalam bidang pelayanan kesehatan.

Dalam perspektif Hukum Administrasi Negara (HAN), pemerintah memiliki peran serta tanggung jawab untuk melakukan kegiatan mengatur dan mengurus pemerintah, melakukan pengaturan untuk meningkatkan kualitas dan menjamin penyediaan pelayanan kesehatan sesuai dengan asas-asas umum pemerintahan yang baik.

Hal demikian menjadi konsekuensi mutlak menimbang pelayanan kesehatan merupakan pelayanan publik yang juga lahir sebagai perintah undang-undang. Pelayanan publik merupakan mandat bagi negara dalam memberikan pelayanan yang terbaik kepada masyarakat. Lebih tegasnya lagi, menurut Undang-Undang Republik Indonesia Nomor 25 Tahun 2009 tentang Pelayanan Publik (UU Pelayanan Publik) Pasal 1 Angka 1, pelayanan publik adalah kegiatan atau rangkaian kegiatan dalam rangka pemenuhan kebutuhan pelayanan sesuai dengan peraturan perundang-undangan bagi setiap warga negara dan penduduk atas barang, jasa, dan/atau pelayanan administratif yang disediakan oleh penyelenggara pelayanan publik. ${ }^{3}$ Berdasarkan pengertian tersebut, kegiatan pelayanan publik pasti diatur pemenuhannya berdasarkan regulasi yang dibuat oleh pemerintah dengan tujuan utamanya untuk memenuhi kebutuhan dasar dan kesejahteraan masyarakat.

Idealnya, semua pelayanan negara sebenarnya dibiayai sendiri oleh masyarakat melalui sistem asuransi dan perpajakan, dengan orientasi utama mendukung human investment. Konsep negara kesejahteraan itu adalah buah dari penerapan sistem ekonomi yang mandiri, produktif dan efisien dengan pendapatan individu yang memungkinkan masyarakat untuk menabung, setelah kebutuhan dasar dalam hidup mereka sudah tercukupi dengan pelayanan publik bebas biaya (gratis) yang diselenggarakan oleh

\footnotetext{
2 Tujuan Negara Indonesia dalam Pembukaan UUD NRI Tahun 1945 Alinea ke-IV: “Kemudian daripada itu untuk membentuk suatu Pemerintahan Negara Indonesia yang melindungi segenap bangsa Indonesia dan seluruh tumpah darah Indonesia dan untuk memajukan kesejahteran umum mencerdaskan kehidupan bangsa dan ikut melaksanakan ketertiban dunia yang berdasar kemerdekaan, perdamaian abadi dan keadilan sosial. Maka disusunlah kemerdekaan Kebangsaan Indonesia itu dalam suatu Undang-Undang Dasar Negara Indonesia, yang terbentuk dalam suatu susunan Negara Republik Indonesia yang berkedaulatan rakyat dengan berdasar kepada Ketuhanan Yang Maha Esa, kemanusian yang adil dan beradap, persatuan Indonesia, kerakyatan yang dipimpin oleh hikmat kebijaksanaan dalam permusyawaratan/perwakilan, serta dengan mewujudkan suatu keadilan sosial bagi seluruh rakyat Indonesia."

3 Solechan. (2019). Asas-Asas Umum Pemerintahan yang Baik dalam Pelayanan Publik. Administrative Law \& Governance Journal. Volume 2 Issue 3, August 2019, h. 549-550.
} 
pemerintah. Maka dari itu untuk mencapai cita-cita negara kesejahteraan (welfare state) tersebut haruslah diselenggarakan pelayanan publik (publik service) yang terjamin kualitasnya. ${ }^{4}$ Menimbang hal tersebut, Pemerintah menetapkan standar kualitas yang memiliki tolak ukur yang jelas sehingga menjamin pelaksanaan yang baik. Pemerintah memberi perlindungan bagi setiap warga negara dan penduduk dari penyalahgunaan wewenang di dalam penyelenggaraan pelayanan kesehatan.

Tanggung jawab pemerintah dalam pelayanan kesehatan, secara gamblang termaktub dalam Undang-Undang Republik Indonesia Nomor 36 Tahun 2009 tentang Kesehatan (UU Kesehatan), yakni merencanakan, mengatur, menyelenggarakan, membina, dan mengawasi penyelenggaraan upaya kesehatan yang merata dan terjangkau oleh masyarakat. ${ }^{5}$ Lebih detailnya, dala konteks pelayanan kesehatan sebagai public services, kewajiban dan tanggung jawab pemerintah adalah terjaminnya:

a. Ketersediaan Iingkungan, tatanan, fasilitas kesehatan baik fisik maupun sosial bagi masyarakat untuk mencapai derajat kesehatan yang setinggi-tingginya.

b. Ketersediaan sumber daya di bidang kesehatan yang adil dan merata bagi seluruh masyarakat untuk memperoleh derajat kesehatan yang setinggi-tingginya.

c. Ketersediaan akses terhadap informasi, edukasi, dan fasilitas pelayanan kesehatan untuk meningkatkan dan memelihara derajat kesehatan yang setinggi-tingginya.

d. Pemberdayaan dan mendorong peran aktif masyarakat dalam segala bentuk upaya kesehatan.

e. Ketersediaan segala bentuk upaya kesehatan yang bermutu, aman, efisien, dan terjangkau.

f. Pelaksanaan jaminan kesehatan masyarakat melalui sistem jaminan sosial nasional bagi upaya kesehatan perorangan. Pelaksanaan sistem jaminan sosial yang dimaksud ini dilaksanakan sesuai ketentuan peraturan perundang-undangan. ${ }^{6}$

Berdasarkan kerangka hukum UU Kesehatan, sumber daya di bidang kesehatan yang harus disediakan oleh pemerintah dan pemerintah daerah adalah anggaran, tenaga kesehatan, perbekalan kesehatan, sediaan farmasi, alat kesehatan dan fasilitas pelayanan dan teknologi kesehatan. Pemerintah daerah berpartisipasi dalam penyediaan layanan kesehatan yang dilakukan melalui penyediaan tenaga kesehatan, rumah sakit daerah, puskesmas, dll. Pemerintah membiayai penyediaan layanan tersebut melalui anggaran daerah (APBD). Untuk dapat mengakses layanan kesehatan tersebut, pada umumnya masyarakat dikenakan pungutan retribusi jasa layanan kesehatan. ${ }^{7}$

Menariknya, pelayanan kesehatan sebagai bagian hak asasi manusia (HAM) masyarakat Indonesia yang telah dijamin konstitusi, menjadi bagian perubahan setelah disahkannya Omnibus Law RUU Cipta Kerja menjadi undang-undang (Undang-Undang

${ }^{4}$ Ibid, h. 551.

5 Pasal 14 ayat 1 UU Kesehatan.

6 Pasal 14-20 UU Kesehatan.

7 Fheriyal Sri Isriawaty. (2015). Tanggung Jawab Negara dalam Pemenuhan Hak Atas Kesehatan Masyarakat Berdasarkan Undang Undang Dasar Negara Republik Indonesia Tahun 1945. Jurnal Ilmu Hukum Legal Opinion Edisi 2, Volume 3, Tahun 2015, h. 7. 
Republik Indonesia Nomor 11 Tahun 2020 tentang Cipta Kerja) ${ }^{8}$. Omnibus Law (UU baru untuk mengamandemen beberapa UU sekaligus), atau secara sederhana dapat diterjemahkan sebagai satu UU yang bisa mengubah banyak UU, ${ }^{9}$ diterapkan, sebagai ikhtiar solutif atas tumpang tindih dan disharmonisnya regulasi. Hadirnya UndangUndang Republik Indonesia Nomor 11 Tahun 2020 tentang Cipta Kerja (UU Cipta Kerja) tersebut diharapkan akan mengakselerasi pemulihan ekonomi mulai tahun 2021 dan mampu merampingkan hyper regulation yang menjadi hambatan pertumbuhan investasi Indonesia selama ini. UU Cipta Kerja diharapkan memberikan lima manfaat bagi perekonomian Indonesia, yakni: pertama, penciptaan lapangan kerja yang diproyeksikan sebanyak 2,7-3 juta per tahun. Kedua, peningkatankompetensi pencari kerja dan kesejahteraan pekerja. Ketiga, peningkatan produktivitas pekerja, yang berpengaruh pada peningkatan investasi dan pertumbuhan ekonomi. Keempat, peningkatan investasi yang diproyeksikan sebesar 6,6-7,0\% untuk membangun usaha baru atau mengembangkan usaha existing yang akan menciptakan lapangan kerja baru dan meningkatkan kesejahteraan pekerja sehingga akan mendorong peningkatan konsumsi (5,4-5,6\%). Kelima, pemberdayaan UMKM dan koperasi, yang mendukung peningkatan kontribusi UMKM terhadap PDB yang diperkirakan menjadi 65\% dan peningkatan kontribusi koperasi terhadap PDB menjadi 5,5\%.10

Di bidang kesehatan, ada 5 (lima) UU bidang kesehatan yang diubah setelah kehadiran UU Cipta Kerja. Kelima UU tersebut yaitu Undang-Undang Republik Indonesia Nomor 36 Tahun 2009 tentang Kesehatan (UU Kesehatan), Undang-Undang Republik Indonesia Nomor 44 Tahun 2009 tentang Rumah Sakit (UU Rumah Sakit), Undang-Undang Republik Indonesia Nomor 5 Tahun 1997 tentang Psikotoprika (UU Psikotoprika), Undang-Undang Republik Indonesia Nomor 35 Tahun 2009 tentang Narkotika (UU Narkotika) dan Undang-Undang Republik Indonesia Nomor 18 Tahun 2012 tentang Pangan (UU Pangan).

Mengingat dampak pemberlakuan UU Cipta Kerja yang luar biasa mengubah peraturan perundang-undangan di sektor kesehatan, menjadi sangat penting untuk menganalisis peran dan tanggungjawab pemerintah dalam pelayanan kesehatan pasca berlakunya UU Cipta Kerja sebagai bagian pemberlakuan Omnibus Law di Indonesia.

\section{Rumusan Masalah}

Agar penelitian tentang peran dan tanggungjawab pemerintah dalam pelayanan kesehatan pasca berlakunya UU Cipta Kerja ini menjadi terarah dan sekaligus untuk menghindarkan kemungkinan pembahasan yang menyimpang dari pokok permasalahan yang ditentukan, maka perlu adanya pembatasan masalah. Masalah yang menjadi fokus penelitian yaitu bagaimana ruang lingkup peran dan tanggungjawab pemerintah dalam

8 https://www.kompas.com/tren/read/2020/10/06/104500965/apa-itu-omnibus-law-ciptakerja-isi-dan-dampaknya-bagi-buruh?page=all, diakses pada 03 April 2021.

9 Suriadinata, Vincent. (2019). Penyusunan Undang-Undang di Bidang Investasi: Kajian Pembentukan Omnibus Law di Indonesia. Refleksi Hukum [Vol. 4, No. 1, 2019], h. 117.

10 Sony Hendra Permana. (2020). Proyeksi Dampak Omnibus Law Undang-Undang Cipta Kerja Terhadap Ekonomi Indonesia. Pusat Penelitian Badan Keahlian DPR RI. Bidang Ekonomi dan Kebijakan Publik. Vol. XII, No.19/I/Puslit/Oktober/2020. 
pelayanan kesehatan pasca berlakunya UU Cipta Kerja dan bagaimanakah bentuk peran dan tanggungjawab pemerintah dalam pelayanan kesehatan pasca berlakunya UU Cipta Kerja.

\section{METODE PENELITIAN}

Penelitian ini berangkat dari pokok persoalan pengundangan UU Cipta Kerja sebagai penerapan Omnibus Law di Indonesia yang berdampak signifikan pada regulasi terutama dalam bidang pelayanan kesehatan. Untuk menjawab permasalahan yang telah dirumuskan dalam penelitian ini, digunakan penelitian hukum normatif. Penelitian hukum normatif dalam konteks penelitian ini, pokok kajiannya adalah peran dan tanggung jawab pemerintah dalam pelayanan kesehatan pasaca berlakunya UU Cipta Kerja di Indonesia.

Dalam penelitian pada umumnya dibedakan antara data yang diperoleh secara langsung dari masyarakat dan dari bahan-bahan pustaka. Yang diperoleh langsung dari masyarakat dinamakan data primer (atau data dasar), sedangkan yang diperoleh dari bahan-bahan pustaka lazimnya dinamakan data sekunder.11 Sesuai dengan tipe penelitian yuridis normatif maka data yang dikumpulkan adalah data sekunder. Pengumpulan data sekunder dimaksudkan sebagai upaya mendapatkan landasan teoritis yakni dengan mempelajari peraturan-peraturan, dokumen-dokumen dan buku-buku yang ada kaitannya dengan masalah ini, serta pendapat para sarjana (doktrin).

Data sekunder di bidang hukum yang digunakan dalam penelitian ini mencakup tiga bagian yaitu:

a. Bahan Hukum Primer yaitu bahan-bahan hukum yang mengikat.

Mengacu pada asas peraturan perundang-undangan yang bersifat khusus menyampingkan peraturan perundang-undangan yang bersifat umum (lex specialis derogat lex generalis) dan asas peraturan perundang-undangan yang berlaku belakangan membatalkan peraturan perundang-undangan yang berlaku terdahulu (lex posteriori derogate lex periori), ${ }^{12}$ maka bahan hokum primer yang peneliti gunakan dalam penelitian ini terdiri dari:

1) Undang-Undang Dasar Negara Republik Indonesia Tahun 1945 (UUD NRI 1945);

2) Undang-Undang Republik Indonesia Nomor 11 Tahun 2020 tentang Cipta Kerja (UU Cipta Kerja);

3) Undang-Undang Republik Indonesia Nomor 44 Tahun 2009 tentang Rumah Sakit (UU Rumah Sakit);

4) Undang-Undang Republik Indonesia Nomor 36 Tahun 2009 tentang Kesehatan (UU Kesehatan);

5) Undang-Undang Republik Indonesia Nomor 25 Tahun 2009 tentang Pelayanan Publik (UU Pelayanan Publik); dan

\footnotetext{
${ }^{11}$ Soerjono Soekanto dan Sri Mamudji. (2011). Penelitian Hukum Normatif. Suatu Tinjauan Singkat, Jakarta: Raja Grafindo Persada. h. 12.

12 Dr. Roy Marthen Moonti SH.,MH. (2017). Ilmu Perundang-Undangan. Makassar: Keretakupa, h. 33.
} 
6) Peraturan Pemerintah Republik Indonesia Nomor 47 Tahun 2021 tentang Penyelenggaraan Bidang Perumahsakitan (PP 47/2021).

b. Bahan Hukum Sekunder adalah bahan hukum yang terdiri atas buku-buku teks yang ditulis para ahli hukum yang berpengaruh, jurnal-jurnal hukum, pendapat para sarjana, kasus-kasus hukum, yurispudensi, dan hasil-hasil simposium mutakhir yang berkaitan dengan penelitian. ${ }^{13}$

c. Bahan hukum tersier adalah bahan hukum yang memberikan petunjuk atau penjelasan terhadap bahan hukum primer dan bahan hukum sekunder seperti kamu hukum, ensiklopedia, dan lain-lain. ${ }^{14}$

Teknik pengumpulan data dalam penelitian ini dilakukan dengan studi pustaka, yaitu suatu cara pengumpulan data dengan melakukan penelusuran dan menelaah bahan pustaka (literatur, hasil penelitian, majalah ilmiah, buletin ilmiah, jurnal ilmiah dsb). Data/bahan hukum yang telah terkumpul melalui proses inventarisasi hukum, kemudian diklasifikasikan untuk selanjutnya dianalisis secara mendalam dengan cara menggali asas, nilai serta norma pokok yang terkandung di dalamnya. Selanjutnya dilakukan cross-check dengan peraturan perundang-undangan yang lain untuk menemukan tarafa sinkronisasi/harmonisasinya, adakah inkonsistensi di antara peraturan perundang-undangan tersebut. Analisis data tersebut dilakukan secara kualitatif melalui penelaahan logika berpikir secara deduktif. ${ }^{15}$ Hasil penelitian disajikan dalam bentuk uraian-uraian yang tersusun secara sistematis, artinya data sekunder yang diperoleh akan dihubungkan satu dengan yang lain disesuaikan dengan permasalahan yang diteliti, sehingga secara keseluruhan merupakan satu kesatuan yang utuh sesuai dengan kebutuhan penelitian.

\section{PEMBAHASAN}

\section{A. Indonesia Sebagai Negara Welfare State}

Para pendiri negara Indonesia telah menyepakati bahwa salah satu tujuan didirikannya negara Indonesia adalah agar keadilan dan kemakmuran bangsa Indonesia bisa diwujudkan. Unsur-unsur welfare state ini telah dimasukkan ke dalam dasar negara Indonesia (Pancasila dan UUD 1945) pada saat persiapan rapat pembahasan persiapan dan paska kemerdekaan negara Indonesia. Pembukaan UUD 1945 yang memuat rumusan tujuan negara Indonesia dan juga Pancasila menyatakan bahwa negara Indonesia dibentuk “... untuk melindungi segenap bangsa Indonesia dan seluruh tumpah darah Indonesia dan untuk memajukan kesejahteraan umum, mencerdaskan kehidupan bangsa, dan ikut melaksanakan ketertiban dunia ... dengan berdasar kepada [disini kemudian teks Pancasila muncul] ... keadilan sosial bagi seluruh rakyat Indonesia."

13 Johnny Ibrahim. (2011). Teori dan Metode Penelitian Hukum Normatif. Cet. 4, Malang: Bayumedia Publishing, 2011, h. 296.

14 Ibid.

${ }^{15}$ Baca Prof. Dr. Suteki, S.H.,M.Hum., dan Galang Taufani, S.H.,M.H (2018). Metodologi Penelitian Hukum (Filsafat, Teori dan Praktik). Depok: Rajawali Pers. h. 267. 
Inti dari dari istilah welfare state adalah tanggung jawab negara terhadap kesejahteraan warganya. Dalam Encyclopedia Britannica, welfare state diartikan sebagai konsep pemerintahan dimana negara memainkan peran kunci dalam menjaga dan memajukan kesejahteraan ekonomi dan sosial warga negaranya.8 Sedangkan the Concise Oxford Dictionary of Politics mendefinisikannya sebagai sebuah sistem dimana pemerintah menyatakan diri bertanggung jawab untuk menyediakan jaminan sosial dan ekonomi bagi penduduk melalui sarana pensiun, tunjangan jaminan sosial, layanan kesehatan gratis dan semacamnya.

Dalam konteks soal tanggung jawab negara dalam soal pemenuhan kebutuhan dasar warganya, welfare state dianggap sebagai mekanisme pemerataan terhadap kesenjangan yang ditimbulkan oleh ekonomi pasar. Jaminan sosial, kesehatan, perumahan dan pendidikan adalah wilayah garapan utama dari kebijakan pemerintah yang menganut welfare state.

Konsep welfare state oleh karena itu biasanya didasarkan pada prinsip persamaan kesempatan (equality of opportunity), pemerataan pendapatan (equitable distribution of wealth), dan tanggung jawab publik (public responsibility) terhadap mereka yang tidak mampu untuk menyediakan sendiri kebutuhan minimum untuk bisa hidup layak.

Rumusan dasar ideologi welfare state di Indonesia sebagaimana yang termaktub dalam Pembukaan UUD NRI 1945 ("memajukan kesejahteraan umum" dan sila kelima Pancasila "keadilan sosial bagi seluruh rakyat Indonesia") kemudian dimanifestasikan ke dalam batang tubuh konstitusi negara Indonesia untuk dijadikan pedoman hidup berbangsa dan penyelenggaraan kenegaraan. Dalam Pasal 34 Konstitusi NRI, tugas negara di bidang kesejahteraan sosial ini diperluas dengan tambahan tanggung jawab untuk mengembangkan sistem jaminan sosial dan memberdayakan kelompok masyarakat miskin, serta memberikan pelayanan kesehatan dan fasilitas pelayanan umum bagi rakyatnya.

\section{B. Pelayanan Kesehatan Sebagai Pelayanan Publik}

Sejak dianutnya konsepsi welfare state (negara kesejahteraan) di Indonesia yang menempatkan pemerintah sebagai pihak yang bertanggung jawab terhadap kesejahteraan umum warga negara dan untuk mewujudkan kesejahteraan tersebut, pemerintah diberi wewenang untuk campur tangan dalam segala lapangan kehidupan masyarakat, yang dalam campur tangan ini tidak saja berdasarkan pada peraturan perundang-undangan, tetapi dalam keadaan tertentu dapat bertindak tanpa bersandar pada peraturan perundang-undangan, tetapi berdasar pada inisiatif sendiri. Adanya keberadaan konsep negara kesejahteraan dengan tujuannya untuk memberikan kesejahteraan bagi seluruh warga negara Indonesia tersebut, secara konstitusional telah menjamin hak akan kesehatan, menuntut adanya reformasi dalam pelayanan publik di berbagai bidang termasuk dalam bidang kesehatan.

Pelayanan kesehatan sebagai bidang pelayanan publik secara tegas diatur dalam Undang-Undang Republik Indonesia Nomor 25 Tahun 2009 tentang Pelayanan Publik (UU tentang Pelayanan Publik) yang menyebutkan bahwa pelayanan kesehatan termasuk golongan barang publik yang tercantum dalam pasal 5 ayat 1 dan 2 yaitu (ayat 1 ) ruang 
lingkup pelayanan publik meliputi pelayanan barang publik serta pelayanan administratif yang diatur dalam peraturan perundang-undangan; (ayat 2) ruang lingkup sebagaimana dimaksud pada ayat 1 meliputi pendidikan, pengajaran, pekerjaan dan usaha, tempat tinggal, komunikasi dan informasi, lingkungan hidup, kesehatan, jaminan sosial, energi, perbankan, perhubungan, sumber daya alam, pariwisata dan sektor strategis lainnya.

Menurut UU Pelayanan Publik Pasal 1 Angka 1, pelayanan publik adalah kegiatan atau rangkaian kegiatan dalam rangka pemenuhan kebutuhan pelayanan sesuai dengan peraturan perundang-undangan bagi setiap warga negara dan penduduk atas barang, jasa, dan/atau pelayanan administratif yang disediakan oleh penyelenggara pelayanan publik. Penyelenggara pelayanan publik itu sendiri ialah setiap institusi penyelenggara negara, korporasi, lembaga independen yang dibentuk berdasarkan undang-undang untuk kegiatan pelayanan publik, dan badan hukum lain yang dibentuk semata-mata untuk kegiatan pelayanan publik. Sedangkan penerima pelayanan publik ialah masyarakat dalam hal ini yang disebut dengan masyarakat ialah seluruh pihak, baik warga negara maupun penduduk sebagai orang-perseorangan, kelompok, maupun badan hukum yang berkedudukan sebagai penerima manfaat pelayanan publik, baik secara langsung maupun tidak langsung.

Pelayanan publik merupakan mandat bagi negara dalam memberikan pelayanan yang terbaik kepada masyarakat. Terdapat tiga pertimbangan mengapa pelayanan publik harus diselenggarakan oleh negara. Pertama, investasinya hanya bisa dilakukan atau diatur oleh negara, seperti pembangunan infrastruktur transportasi, pemberian layanan administrasi negara, perizinan, dan lain-lain. Kedua, sebagai kewajiban negara karena posisi negara sebagai penerima mandat. Dan ketiga, biaya pelayanan publik di danai dari uang masyarakat, baik melalui pajak maupun mandat masyarakat kepada negara untuk mengelola sumber kekayaan negara. ${ }^{16}$ Dimasukannya kesehatan sebagai salah satu bidang dalam pelayanan publik menunjukan bahwa pelayanan kesehatan merupakan salah satu komponen penting dalam aspek kehidupan bernegara. Sehingga dalam UU Kesehatan yang menjadi landasan pembangunan kesehatan di Indonesia dalam pasal 2 ditetapkan bahwa "Pembangunan kesehatan diselenggarakan dengan berasaskan perikemanusiaan, keseimbangan, manfaat, perlindungan, penghormatan terhadap hak dan kewajiban, keadilan, genderdan non diskriminatif dan norma-norma agama."

\section{Asas-Asas Pelayanan Umum yang Baik}

Keaktifan pemerintah dalam pelayanan kesehatan sebagai pelayanan publik dalam perwujudan kesejahteraan di bidang kesehatan haruslah senantiasa berdasarkan pada asas-asas umum pemerintahan yang baik (selanjutnya disebut AAUPB).

Tindakan atau campur tangan pemerintah dalam konsep negara kesejahteraan (welfare state) sebagai pihak yang bertanggung jawab untuk mewujudkan kesejahteraan dan kemakmuran warga masyarakatnya semakin besar. Sebagai negara hukum, maka tindakan pemerintah untuk memberikan kesejahteraan tersebut juga harus berdasarkan peraturan perundang-undangan yang berlaku atau sering bertindak berdasarkan freies

16 Ainur Rofieq. (2011). "Pelayanan Publik dan Welfare State”, Governance, 2, h. 551. 
ermessen, namun tindakan tersebut sering menimbulkan penyalahgunaan wewenang yang mengakibatkan terjadi benturan kepentingan antara warga masyarakat dengan pemerintah.

AAUPB dapat di ibaratkan sebagai rambu lalu lintas dan pedoman perjalanan dalam rangka memperlancar hubungan pemerintahan yaitu antara pemerintah dan yang diperintah atau warga masyarakat. AAUPB selanjutnya dijadikan sebagai dasar penilaian dan upaya administrasi, di samping sebagai norma hukum tidak tertulis bagi tindakan pemerintah. ${ }^{17}$

Asas-asas umum pemerintahan yang baik juga perlu diterapkan dalam pelaksanaan pelayanan publik dengan tujuan :

1. Terwujudnya batasan dan hubungan yang jelas tentang hak, tanggung jawab, kewajiban, dan kewenangan seluruh pihak yang terkait dengan penyelenggaraan pelayanan publik;

2. Terwujudnya sistem penyelenggaraan pelayanan publik sesuai dengan asas-asas umum pemerintahan dan korporasi yang baik;

3. Terpenuhinya penyelenggaraan pelayanan publik sesuai dengan peraturan perundangundangan; dan

4. Terwujudnya perlindungan dan kepastian hukum bagi masyarakat dalam penyelenggaraan pelayanan publik.

Pada pasal 10 Undang-Undang Nomor 30 Tahun 2014 tentang Administrasi Pemerintahan menguraikan ruang lingkup AUPB yang berlaku dalam administrasi pemerintahan. Asas Umum Pemerintahan yang Baik yang dimaksud meliputi asas:

1. kepastian hukum. Asas kepastian hukum merupakan asas dalam negara hukum yang mengutamakan landasan ketentuan peraturan perundang-undangan, kepatutan, keajegan, dan keadilan dalam setiap kebijakan penyelenggaraan pemerintahan.

2. kemanfaatan. Asas kemanfaatan maksudnya manfaat yang harus diperhatikan secara seimbang antara: (1) kepentingan individu yang satu dengan kepentingan individu yang lain; (2) kepentingan individu dengan masyarakat;(3) kepentingan Warga Masyarakat dan masyarakat asing; (4) kepentingan kelompok masyarakat yang satu dan kepentingan kelompok masyarakat yang lain; (5) kepentingan pemerintah dengan Warga Masyarakat; (6) kepentingan generasi yang sekarang dan kepentingan generasi mendatang; (7) kepentingan manusia dan ekosistemnya; (8) kepentingan pria dan wanita.

3. Ketidakberpihakan. Asas ketidakberpihakan adalah asas yang mewajibkan Badan dan/atau Pejabat Pemerintahan dalam menetapkan dan/atau melakukan Keputusan dan/atau Tindakan dengan mempertimbangkan kepentingan para pihak secara keseluruhan dan tidak diskriminatif.

4. Kecermatan. Asas kecermatan dimaksudkan sebagai asas yang mengandung arti bahwa suatu Keputusan dan/atau Tindakan harus didasarkan pada informasi dan dokumen yang lengkap untuk mendukung legalitas penetapan dan/atau pelaksanaan

17 Widjiastuti, Agustin. (2017). "Peran AAUPB dalam Mewujudkan Penyelenggaraan Pemerintahan yang Bersih dan Bebas dari KKN", Perspektif, 22.2, h. 96-110. 
Keputusan dan/atau Tindakan sehingga Keputusan dan/atau Tindakan yang bersangkutan dipersiapkan dengan cermat sebelum Keputusan dan/atau Tindakan tersebut ditetapkan dan/atau dilakukan.

5. Tidak menyalahgunakan kewenangan. Asas tidak menyalahgunakan kewenangan adalah asas yang mewajibkan setiap Badan dan/atau Pejabat Pemerintahan tidak menggunakan kewenangannya untuk kepentingan pribadi atau kepentingan yang lain dan tidak sesuai dengan tujuan pemberian kewenangan tersebut, tidak melampaui, tidak menyalahgunakan, dan/atau tidak mencampuradukkan kewenangan.

6. Keterbukaan. Asas keterbukaan adalah asas yang melayani masyarakat untuk mendapatkan akses dan memperoleh informasi yang benar, jujur, dan tidak diskriminatif dalam penyelenggaraan pemerintahan dengan tetap memperhatikan perlindungan atas hak asasi pribadi, golongan, dan rahasia negara.

7. Kepentingan umum. Asas kepentingan umum adalah asas yang mendahulukan kesejahteraan dan kemanfaatan umum dengan cara yang aspiratif, akomodatif, selektif, dan tidak diskriminatif.

8. Pelayanan yang baik. Asas pelayanan yang baik dimaksudkan sebagai asas yang memberikan pelayanan yang tepat waktu, prosedur dan biaya yang jelas, sesuai dengan standar pelayanan, dan ketentuan peraturan perundang-undangan.

Penerapan asas-asas umum pemerintahan yang baik dalam pelaksanaan pelayanan publik dalam rangka mewujudkan kesejahteraan masyarakat selain daripada yang disebutkan dalam pasal 10 Undang-Undang Nomor 30 Tahun 30014 tentang Administrasi Pemerintahan menguraikan ruang lingkup AUPB yang berlaku dalam administrasi pemerintahan, antara lain: ${ }^{18}$

1. Asas Keseimbangan. Asas ini menghendaki adanya keseimbangan antara hukuman jabatan dan kelalaian atau kealpaan seorang pegawai. Asas ini menghendaki pula adanya kualifikasi yang jela mengenai jenis-jenis atau kualifikasi pelanggaran atau kealpaan yang dilakukan oleh seseorang sehingga memudahkan penerapannya dalam setiap kasus yang ada dan seiring dengan persamaan perlakuan serta sejalan dengan kepastian hukum.

2. Asas Tidak Mencampuradukkan Kewenangan. Seorang pejabat pemerintahan memiliki wewenang yang sudah ditentukan dalam peraturan perundang-undangan baik dari segi materi, wilayah, maupun waktu. Aspek-aspek wewenang ini tidak dapat dijalankan melebihi apa yang sudah ditentukan dalam peraturan yang berlaku.

3. Asas Keadilan dan Kewajaran. Asas keadilan ini menuntut tindakan secara proporsional, sesuai, seimbang, dan selaras dengan hak setiap orang. Sedangkan asas kewajaran menekankan agar setiap aktivitas pemerintah atau administrasi negara memperhatikan nilai-nilai yang berlaku ditengah masyarakat, baik berkaitan dengan agama, moral, adat istiadat, maupun nilai-nilai lainnya.

AAUPB dapat dijadikan landasan atau pedoman bagi aparat pemerintah dalam menjalankan tugasnya, sekaligus sebagai alat uji bagi lembaga peradilan dalam menilai tindakan pemerintah ketika ada gugatan dari pihak lain yang dirasakan merugikannya.

${ }^{18}$ HR, Ridwan. (2014). Hukum Administrasi Negara. Jakarta: PT Raja Grafindo Persada. 
Dengan kata lain, AAUPB secara teoritis sangat penting dalam mewujudkan pemerintahan yang bersih, berwibawa, dan berkualitas baik di pusat maupun di daerah. Secara yuridis, cerminan pemerintah yang demikian dapat dilihat dari produk hukum yang ditetapkannya, seperti dalam wujud perizinan daerah yang berwawasan lingkungan hidup. ${ }^{19}$

\section{Peranan dan Tanggungjawab Pemerintah dalam Pelayanan Kesehatan Pasca Berlakunya UU Cipta Kerja}

Ada 45 peraturan pemerintah dan 4 peraturan presiden sebagai aturan turunan berlakunya UU Cipta Kerja. ${ }^{20}$ Dalam konteks peranan dan tanggungjawab pemerintah dalam pelayanan kesehatan pasca berlakunya UU Cipta Kerja, Peraturan Pemerintah Nomor 47 Tahun 2021 tentang Penyelenggaraan Bidang Perumahsakitan (PP 47/2021) adalah delegasi dari undang-undang tersebut. Undang-undang di bidang kesehatan yang mengalami perubahan sebagai konsekuensi pasca pemberlakuan UU Cipta Kerja antara lain UU 36/2009 tentang Kesehatan, UU 44/2009 tentang Rumah Sakit, UU 5/1997 tentang Psikotropika, dan UU 35/2009 tentang Narkotika.

Pasca Berlakunya UU Cipta Kerja, pemerintah cq Kementerian Kesehatan diberikan delegasi dalam pengaturan Norma, Standar, Prosedur dan Kriteria (NSPK) dalam PP 47/2021 bersama-sama dengan pemerintah daerah terkait, organisasi profesi dan asosiasi perumahsakitan untuk melaksanakan UU No. 11/2020 dan PP No. 47/2021, dengan memperhatikan setiap klausul yang ada terhadap asas pembentukan peraturan perundang-undangan. Ada beberapa poin perubahan di bidang kesehatan dalam UU Cipta Kerja, diantaranya adalah :

a) Penyederhanaan pasal-pasal dalam UU Kesehatan dan UU Rumah Sakit

Dalam UU Kesehatan terjadi perampingan pasal-pasal, diantaranya:

1) Undang - Undang Nomor 36 Tahun 2009 tentang Kesehatan

Perampingan terjadi pada Pasal 30 dari 5 ayat menjadi 4 ayat, pasal 111 tentang makanan dan minuman yang dikonsumsi masyarakat dari 6 ayat dirampingkan menjadi 4 ayat dan pasal 188 tentang tindakan administratif bagi nakes dan fasyankes yang melanggar aturan, dari 4 ayat dirampingkan menjadi hanya 1 ayat.

2) Undang - Undang Nomor 44 Tahun 2009 tentang Rumah Sakit

Perubahan dalam pasal 24 (1) menyebutkan klasifikasi rumah sakit berdasarkan kemampuan pelayanan, sarana penunjang dan sumber daya manusia. Pada pasal 62 tentang sanksi administratif terhadap penyelenggaraan rumah sakit tanpa izin dendanya dinaikkan dari Rp 5.000.000.000 menjadi Rp 7.000.000.000.

19 Muhammad Azhar. (2015). "Relevansi Asas-Asas Umum Pemerintahan Yang Baik" dalam Relevansi Asas-Asas Umum Pemerintahan yang Baik dalam Sistem Penyelenggaraan Administrasi Negara, $8.5,274-87$.

20 Baca TEMPO. (2021). Pemerintah Terbitkan Aturan Turunan UU Cipta Kerja, https://nasional.tempo.co/read/1435018/ pemerintah-terbitkan-aturan-turunan-uu-ciptakerja-berikut-daftarnya/full\&view $=$ ok, diakses pada 10 Juni 2021. 
b) Jasa Pelayanan Kesehatan Medis

1) Jasa pelayanan kesehatan medis tidak dikenakan PPN

Aturan UU Cipta Kerja menyebutkan bahwa jasa pelayanan kesehatan medis tidak dikenai Pajak Pertambahan Nilai (PPN). Sehingga dalam pemberian jasa pelayanan kesehatan di fasilitas kesehatan tingkat pertama dan jasa pelayanan medis di fasilitas kesehatan rujukan tingkat lanjut, baik instansi negeri maupun swasta tidak dilakukan pemotongan PPN akan tetapi dikenakan potongan terhadap pajak penghasilan.

2) Pemberian Jasa pelayanan kesehatan medis tidak hanya pada tenaga kesehatan dan asisten tenaga kesehatan

Pemberian jasa pelayanan kesehatan medis tidak hanya pada tenaga kesehatan dan asisten tenaga kesehatan saja akan tetapi pada beberapa jenis pekerjaan yang sebelumnya belum ada regulasi khususnya di bidang kesehatan. Ketentuan UU Cipta Kerja mengakui keberadaan paranormal dan memasukkan paranormal sebagai jasa pengobatan alternatif. Hal ini dapat ditemukan pada UU Cipta Kerja Pasal 4A (3) huruf a tentang jasa pelayanan kesehatan medis. Ada 8 layanan yang dimasukkan dalam kesehatan medis, yang salah satunya adalah paranormal, yaitu:

1. jasa dokter umum, dokter spesialis, dan dokter gigi,

2. dokter hewan,

3. ahli kesehatan seperti ahli akupuntur, ahli gigi, ahli gizi, dan ahli fisioterapi,

4. kebidanan dan dukun bayi,

5. paramedis dan perawat,

6. rumah sakit, rumah bersalin, klinik kesehatan, laboratorium kesehatan, dan sanatorium,

7. serta psikolog dan psikiater.

8. pengobatan alternatif termasuk paranormal.

c) Akreditasi Rumah Sakit

UU Cipta Kerja mengharuskan rumah sakit melakukan akreditasi setiap tiga tahun sekali. Tujuan akreditasi adalah meningkatkan mutu layanan yang diberikan rumah sakit kepada masyarakat umum. ${ }^{21}$

d) Tidak menyinggung Puskesmas

Pusat Kesehatan Masyarakat (Puskesmas) tidak disebutkan dalam UU Cipta Kerja, baik terkait layanan medis maupun layanan kesehatan lainnya. Artinya, dengan tidak adanya perubahan dalam UU Cipta Kerja tentang puskesmas, bisa diartikan bahwa semua ketentuan tentang Puskesmas masih berpedoman pada Peraturan Menteri Kesehatan Republik Indonesia Nomor 43 Tahun 2019 tentang Pusat Kesehatan Masyarakat.

${ }^{21}$ Baca Pasal 40 (1) UU Cipta Kerja. 
Terkait hal tersebut di atas, sesuai UU Kesehatan, pemerintah bertanggung jawab merencanakan, mengatur, menyelenggarakan, membina, dan mengawasi penyelenggaraan upaya kesehatan yang merata dan terjangkau oleh masyarakat. Pemerintah juga bertanggung jawab dalam hal ketersediaan lingkungan, tatanan, fasilitas kesehatan baik fisik maupun sosial bagi masyarakat; ketersediaan sumber daya di bidang kesehatan yang adil dan merata bagi seluruh masyarakat; ketersediaan akses terhadap informasi, edukasi, dan fasilitas pelayanan kesehatan; memberdayakan dan mendorong peran aktif masyarakat dalam segala bentuk upaya kesehatan; dan ketersediaan segala bentuk upaya kesehatan yang bermutu, aman, efisien, dan terjangkau.22 Karena itulah, pemerintah bertanggung jawab melaksanakan jaminan kesehatan masyarakat melalui sistem jaminan sosial nasional bagi upaya kesehatan perorangan yang pelaksanaannya harus dilaksanakan sesuai ketentuan peraturan perundang-undangan.

Secara konkret, dalam pelayanan kesehatan pasca berlakunya UU Cipta Kerja, pemerintah mempunyai peranan vital dalam aspek sebagai berikut:

1). Pengaturan praktik pelayanan kesehatan di rumah sakit yaitu berupa pembinaan dan pengawasan terhadap rumah sakit dengan melibatkan organisasi profesi, asosiasi perumahsakitan, dan organisasi kemasyaratan lainnya sesuai dengan tugas dan fungsi masing- masing yang dilakukan oleh pemerintah dan pemerintah daerah (Pasal 54 ayat (1) UU No. 44 Tahun 2009 tentang Rumah Sakit). Pembinaan dan pengawasan rumah sakit penting, bertujuan untuk:

1) Pemenuhan kebutuhan pelayanan kesehatan yang terjangkau oleh masyarakat

2) Peningkatan mutu pelayanan kesehatan

3) Keselamatan pasien

4) Pengembangan jangkauan pelayanan

5) Peningkatan kemampuan kemandirian rumah sakit (Pasal 62 ayat (2) UU Rumah Sakit).

2). Meminimalisir pembuatan kebijakan yang merugikan kepentingan tenaga kesehatan yang bekerja di rumah sakit.

Kebijakan internal rumah sakit milik negara yang merugikan dapat diminimalisir dengan membuat mekanisme banding administrasi. Terkait rumah sakit atau fasilitas pelayanan kesehatan swasta kembali lagi kepada fungsi pengawasan yang wajib dilakukan oleh pemerintah dan pemerintah daerah yang diatur dalam UU Rumah Sakit (Pasal 54-61).

3). Memastikan masyarakat mendapatkan pelayanan kesehatan sesuai standar dan mutu yang representatif

Salah satu cara pemerintah untuk dapat memastikan semua masyarakat mendapatkan pelayanan kesehatan sesuai standar dan mutu diatur dalam ketentuan Pasal 22 Undang-Undang Kesehatan, yang menyatakan bahwa penyelenggara pelayanan atau tenaga kesehatan harus memiliki kualifikasi minimum. Kualifikasi ini

${ }^{22}$ Pasal 14 ayat (1) UU No. 36 Tahun 2009 tentang Kesehatan. 
juga harus dibuktikan dengan izin yang diberikan pemerintah, seperti Surat Izin Praktik (SIP) dan Surat Tanda Registrasi (STR).

Penyelenggara pelayanan dapat dikatakan telah memenuhi pelayanan yang baik apabila, telah memenuhi ketentuan dalam UU Pelayanan Publik yang diantaranya menyangkut perbuatan yang sesuai dengan kompetensi dan standar operasional prosedur. Kaitan kekuatan hukum administrasi dalam memberikan perlindungan hukum bagi penyelenggara pelayanan di bidang kesehatan adalah dalam rangka penyelenggara pelayanan diduga melakukan pelanggaran pelayanan.

Apabila pemerintah kurang cepat dan tanggap atas pelayanan kesehatan, seperti dengan adanya persoalan kapasitas pelayanan (terdapat fasilitas yang tidak memadai, tidak terpenuhinya mutu pelayanan kesehatan) dan kurangnya sumber daya manusia (dokter, perawat, dan tenaga kesehatan lainnya, serta timpangnya rasio tenaga kesehatan dengan jumlah pasien) pihak yang merasa tidak terpenuhi haknya dapat mengajukan gugatan.

\section{PENUTUP}

Pemerintah sebagai penanggungjawab terhadap perencanaan, pengaturan, penyelenggaraan, pembinaan, dan pengawasan penyelenggaraan upaya kesehatan yang merata dan terjangkau oleh masyarakat, melalui UU Ciptaker mengubah aturan di bidang kesehatan seperti penyederhanaan pasal-pasal dalam UU Kesehatan dan UU Rumah Sakit, jasa pelayanan kesehatan medis tidak dikenakan PPN, pemberian jasa pelayanan kesehatan medis tidak hanya pada tenaga kesehatan dan asisten tenaga kesehatan, dan mengharuskan rumah sakit melakukan akreditasi setiap tiga tahun sekali. Lebih konkretnya, pemerintah berperan dalam pengaturan praktik pelayanan kesehatan di rumah sakit berupa pembinaan dan pengawasan terhadap rumah sakit, meminimalisir pembuatan kebijakan yang merugikan kepentingan tenaga kesehatan yang bekerja di rumah sakit, dan memastikan masyarakat mendapatkan pelayanan kesehatan sesuai standar dan mutunya.

Pelayanan kesehatan sebagai eksistensi pelayanan publik oleh pemerintah, apabila ada pihak yang kepentingannya dirugikan atas munculnya keputusan atau tindakan factual pemerintah, maka pihak yang merasa tidak terpenuhi haknya dapat mengajukan gugatan ke Pengadilan Tata Usaha Negara (PTUN) sebagai wadah bagi masyarakat untuk mencari keadilan.

\section{DAFTAR PUSTAKA}

\section{Buku dan Jurnal:}

Ainur Rofieq. (2011). "Pelayanan Publik dan Welfare State”, Governance, 2.

Alfitri, (2012). Ideologi Welfare State dalam Dasar Negara Indonesia: Analisis Putusan Mahkamah Konstitusi Terkait Sistem Jaminan Sosial Nasional. Jurnal Konstitusi, Volume 9, Nomor 3, September 2012.

Dr. Roy Marthen Moonti SH., MH. (2017). Ilmu Perundang-Undangan. Makassar: Keretakupa. 
Fheriyal Sri Isriawaty. (2015). Tanggung Jawab Negara dalam Pemenuhan Hak Atas Kesehatan Masyarakat Berdasarkan Undang Undang Dasar Negara Republik Indonesia Tahun 1945. Jurnal Ilmu Hukum Legal Opinion Edisi 2, Volume 3, Tahun 2015.

Johnny Ibrahim. (2011). Teori dan Metode Penelitian Hukum Normatif. Cet. 4, Malang: Bayumedia Publishing.

Muhammad Azhar. (2015). "Relevansi Asas-Asas Umum Pemerintahan yang Baik" dalam Relevansi Asas-Asas Umum Pemerintahan yang Baik dalam Sistem Penyelenggaraan Administrasi Negara, 8.5.

Prof. Dr. Suteki, S.H., M.Hum., dan Galang Taufani, S.H.,M.H. (2018). Metodologi Penelitian Hukum (Filsafat, Teori dan Praktik). Depok: Rajawali Pers.

Ridwan. (2014). Hukum Administrasi Negara. Jakarta: PT Raja Grafindo Persada.

Soerjono Soekanto dan Sri Mamudji. (2011). Penelitian Hukum Normatif. Suatu Tinjauan Singkat, Jakarta: Raja Grafindo Persada.

Solechan. (2019). Asas-Asas Umum Pemerintahan yang Baik dalam Pelayanan Publik. Administrative Law \& Governance Journal. Volume 2 Issue 3, August 2019.

Sony Hendra Permana. (2020). Proyeksi Dampak Omnibus Law Undang-Undang Cipta Kerja Terhadap Ekonomi Indonesia. Pusat Penelitian Badan Keahlian DPR RI. Bidang Ekonomi dan Kebijakan Publik. Vol. XII, No.19/I/Puslit/Oktober/2020.

Suriadinata, Vincent. (2019). Penyusunan Undang-Undang di Bidang Investasi: Kajian Pembentukan Omnibus Law di Indonesia. Refleksi Hukum [Vol. 4, No. 1, 2019]

Widjiastuti, Agustin. (2017). "Peran AAUPB dalam Mewujudkan Penyelenggaraan Pemerintahan yang Bersih dan Bebas dari KKN", Perspektif, 22.2.

Peraturan Perundang-Undangan:

Undang-Undang Dasar Negara Republik Indonesia Tahun 1945

Undang-Undang Republik Indonesia Nomor 11 Tahun 2020 tentang Cipta Kerja

Undang-Undang Republik Indonesia Nomor 44 Tahun 2009 tentang Rumah Sakit

Undang-Undang Republik Indonesia Nomor 36 Tahun 2009 tentang Kesehatan

Undang-Undang Republik Indonesia Nomor 25 Tahun 2009 tentang Pelayanan Publik

Peraturan Pemerintah Republik Indonesia Nomor 47 Tahun 2021 tentang Penyelenggaraan Bidang Perumahsakitan

\section{Internet:}

TEMPO. (2021). Pemerintah Terbitkan Aturan Turunan UU Cipta Kerja, https://nasional.tempo.co/read/1435018/pemerintah-terbitkan-aturan-turunan-uucipta-kerja-berikut-daftarnya/full\&view=ok, diakses pada 10 Juni 2021.

https://www.kompas.com/tren/read/2020/10/06/104500965/apa-itu-omnibus-lawcipta-kerja-isi-dan-dampaknya-bagi-buruh?page=all, diakses pada 03 April 2021. 